\title{
ANALISIS PENGGUNAAN SIKA TILEFIX-200 TA SEBAGAI PENGGANTI SEMEN TERHADAP KUAT TEKAN PADA BETON MUTU K.200
}

\author{
Asri Mulyadi ${ }^{1)}$, Ahmad Dumyati ${ }^{2)}$ \\ Program Studi Teknik Sipil Fakultas Teknik Universitas Palembang \\ Jalan Dharmapala No.1A Bukit Besar Palembang 30139 \\ e-mail : asri_anang@yahoo.co.id ${ }^{1)}$,dumyatiahmad@yahoo.co.id ${ }^{2)}$
}

\begin{abstract}
ABSTRAK
Beton adalah campuran dari agregat halus dan agregat kasar (pasir, kerikil, batu pecah, atau jenis agregat lain) dengan semen yang dipersatukan oleh air dalam perbandingan tertentu dicampur bersama-sama sampai campuran menjadi homogen dan bersifat plastis sehingga mudah untuk dikerjakan. Salah satu bahan yang dapat digunakan sebagai bahan pengganti penyusun beton adalah Sika Tilefix-200TA. Dengan pertimbangan tersebut, maka dilakukan penelitian mengenai pengaruh Sika Tilefix-200TA sebagai bahan pengganti semen pada campuran beton. Penelitian ini bertujuan untuk mengetahui pengaruh kuat tekan beton pada masing-masing variasi pengganti semen pada campuran beton yang menghasilkan kuat tekan optimum dan agregat halus (pasir) dari sungai musi, sedangkan agregat kasar dari lahat. Pada penelitian ini benda uji dicetak dengan menggunakan kubus baja ukuran $15 \mathrm{~cm} \times 15 \mathrm{~cm} \times 15 \mathrm{~cm}$, masing-masing umur yaitu 7 hari, 14 hari, 21 hari dan 28 hari dengan pengujian kuat tekan beton. Pada campuran beton K.200 tersebut dibuat campuran pengganti semen yang berfariasi yaitu dengan campuran SIKA TILEFIX-200T 0\% (normal), campuran SIKA TILEFIX-200T 10\% dari berat semen, campuran SIKA TILEFIX-200T 20\% dari berat semen dan campuran SIKA TILEFIX-200T 30\% dari berat semen. Beton yang mencapai umur 28 hari karena pada umur ini menurut PBI 1974, kekuatan beton telah mencapai 100\%. Dari evaluasi hasil uji kuat tekan yaitu pada beton normal dengan umur 28 hari didapat kuat tekan beton sebesar $202,29 \mathrm{~kg} / \mathrm{cm}^{2}$, pada campuran Sika Tilefix-200TA pengganti semen 10\% dengan umur 28 hari didapat kuat tekan beton sebesar $197,76 \mathrm{~kg} / \mathrm{cm}^{2}$, pada campuran Sika Tilefix-200TA pengganti semen 20\% dengan umur 28 hari didapat kuat tekan beton sebesar $193,23 \mathrm{~kg} / \mathrm{cm}^{2}$ dan campuran Sika Tilefix-200TA pengganti semen 30\% dengan dengan umur 28 hari didapat kuat tekan beton sebesar 190,21 kg/ $\mathrm{cm}^{2}$. Dari hasil evaluasi kuat tekan beton yang menggunakan Sika Tilefix-200TA pengganti semen sebesar 10\%, 20\% dan $30 \%$ tidak mempunyai kuat tekan yang melebihi dari beton normal.
\end{abstract}

\section{PENDAHULUAN}

\section{A. Latar Belakang}

Beton adalah campuran dari agregat halus dan agregat kasar (pasir, kerikil, batu pecah, atau jenis agregat lain) dengan semen yang dipersatukan oleh air dalam perbandingan tertentu [1]. Beton juga dapat didefinisikan sebagai bahan bangunan dan konstruksi yang sifat-sifatnya dapat ditentukan terlebih dahulu dengan mengadakan perencanaan dan pengawasan yang teliti terhadap bahan-bahan yang dipilih [1]. Bahan-bahan pilihan itu adalah semen, air, dan agregat. Agregat dapat berupa kerikil, batu pecah, agregat ringan buatan, pasir, atau bahan sejenis lainnya. Karena hidrasi semen oleh adukan tersebut akan mengeras atau membatu, dan memiliki kekerasan dan kekuatan yang dapat dimanfaatkan untuk berbagai tujuan [2]. Suatu konstruksi beton memerlukan bahan-bahan dasar tertentu yang digunakan sebagai pembentuk beton, yaitu air, semen dan agregat kasar maupun halus. Untuk mendapatkan beton dengan mutu optimal yang akan digunakan dalam suatu struktur konstruksi beton memerlukan beberapa perencanaan desain 
campuran beton[3]. Salah satu bahan yang dapat digunakan sebagai bahan pengganti penyusun beton adalah Sika Tilefix-200TA. Dengan pertimbangan tersebut, maka dilakukan penelitian mengenai pengaruh Sika Tilefix-200TA sebagai bahan pengganti semen pada campuran beton.

\section{B. Tujuan Penelitian}

Adapun tujuan penelitian ini adalah :

1. Untuk mengetahui pengaruh kuat tekan beton pada masing-masing variasi pengganti semen.

2. Mengetahui persentase pengganti semen pada campuran beton yang menghasilkan kuat tekan optimum.

\section{Manfaat Penelitian}

Penelitian ini diharapakan dapat memberikan manfaat :

1. Memberikan data dan informasi kepada produsen beton mengenai persentase pengganti semen (Sika Tilefix-200TA) yang baik untuk digunakan dalam pembuatan beton.

2. Memberikan kontribusi terhadap perkembangan teknologi beton.

\section{Rumusan Masalah}

Rumusan masalah yang akan dikaji dalam penelitian ini adalah :

1. Apakah pengaruh penggantian sebagian semen dengan Sika Tilefix-200TA.

2. Berapa persentase Sika Tilefix-200TA pada campuran beton untuk mendapatkan kuat tekan optimum.

\section{E. Batasan Masalah}

Adapun beberapa batasan masalah agar penelitian terarah dan sesuai tujuan, antara lain :

1. Jenis beton dengan campuran Sika Tilefix200TA.

2. Kuat tekan rencana beton sebesar $16.9 \mathrm{MPa}$ (K200).

3. Variasi penggunaan Sika Tilefix-200TA. Sebagai bahan pengganti sebagai semen pada campuran adalah $0 \%, 10 \%, 20 \%$ dan $30 \%$ terhadap volume semen.

4. Semen yang digunakan adalah semen PCC merek Baturaja.

5. Agregat kasar yang digunakan adalah batu pecah dari Lahat.
6. Pasir yang digunakan berasal dari Sungai Musi, Palembang.

7. Pengujian berupa uji kuat tekan yang dilakukan setelah beton mencapai umur 7 hari, 14 hari, 21 hari, dan 28 hari.

\section{TINJAUAN PUSTAKA}

\section{A. Pengertian Beton}

Beton adalah campuran dari agregat halus dan agregat kasar (pasir, kerikil, batu pecah, atau jenis agregat lain) dengan semen yang dipersatukan oleh air dalam perbandingan tertentu[4]. Beton juga dapat didefinisikan sebagai bahan bangunan dan konstruksi yang sifat-sifatnya dapat ditentukan terlebih dahulu dengan mengadakan perencanaan dan pengawasan yang teliti terhadap bahan-bahan yang dipilih[4].

\section{B. Sifat-sifat umum Beton}

Pada umumnya beton terdiri dari kurang lebih $15 \%$ semen, $8 \%$ air, 3\% udara, selebihnya pasir dan kerikil. Campuran tersebut setelah mengeras mempunyai sifat yang bebeda-beda, tergantung pada cara pembuatannya. Perbandingan campuran, cara mencampur, cara mengangkut, cara mencetak, cara memadatkan, cara merawat, dan sebagainya akan mempengaruhi sifat-sifat beton[4].

Sifat-sifat beton yang akan diuraikan tidak selalu semua harus dimiliki oleh setiap konstruksi beton, dan sifat-sifat tersebut relative ditinjau dari sudut pemakaian beton itu sendiri. Misalnya suatu kolom bangunan, yang terpenting harus memiliki kekuatan tekan yang tinggi yang cukup kuat untuk menahan beban bangunan itu, sedang sifat kerapatan air tidak penting untuk diperhatikan, sebaliknya lantai suatu bak air harus memiliki sifat rapat air. Dengan kata lain, sifat-sifat penting dari beton yang harus ada dalam suatu konstruksi harus disesuaikan dengan kebutuhan, sehingga konstruksi lebih ekonomis.

\section{Material Pembentuk Beton}

Bahan pengikat hidrolik untuk pembuatan beton, dimana hidrolik berarti bila semen bereaksi dengan air yang akan membentuk suatu massa batuan. Semen adalah hasil fabrikasi dimana dapat diproduksi berbagai jenis semen dengan sifat-sifat dan karakteristik berlainan [5]. 
Semen memiliki 4 senyawa kimia yang komplek, terdiri dari :

1) Dicalsium Silikat (2CaO $\mathrm{SiO} 2)$ disingkat CS2.

2) Tricalsium Silikat $\left(3 \mathrm{CaO} \mathrm{SiO}_{2}\right)$ disingkat C3S.

3) Tricalcium Aluminate $\left(3 \mathrm{CaO} \quad \mathrm{Al}_{2} \mathrm{O}_{3}\right)$ disingkat $\mathrm{C}_{3} \mathrm{~A}$.

4) Tetracalsium Alumino Ferrite $(4 \mathrm{CaO}$ $\mathrm{Al} 2 \mathrm{O} 3 \mathrm{Fe} 2 \mathrm{O} 3$ ) disingkat C4AF.

\section{Metode Standar Nasional Indonesia}

Ada beberapa cara dalam mengerjakan rancangan campuran beton, antara lain menurut cara Inggris (British Standard) dan rancangan menurut Amerika (American Concrete Institute / ACI).

Di Indonesia rancangan ini dikenal dengan nama cara DOE (Departement of Environment). Cara ini dipakai sebagai standar perencanaan oleh Departemen Pekerjaan Umum, dan dimuat dalam buku Standar No. SK.SNI.T-15-1990-3 dengan judul buku "Tata Cara Pembuatan Rencana Campuran Beton Normal".

\section{E. Rumus Pengolahan Data Hasil Uji Kuat Tekan Beton}

Setelah memperoleh data dari hasil uji kuat tekan beton, maka data tersebut diolah dengan menggunakan rumus ketentuan dari SK.SNI.T-15-1990-03 sebagai berikut :

$$
\sigma b^{\prime}=\frac{W}{A}
$$

Dengan :

$\sigma b^{\prime}=$ Kuat tekan beton masing-masing sample $\left(\mathrm{kg} / \mathrm{cm}^{2}\right)$

$\mathrm{W}=$ Berat beban masing-masing sample $(\mathrm{kg})$

A $=$ Luas penampang kubus $\left(\mathrm{cm}^{2}\right)$

$$
\sigma b m=\frac{\sum \sigma b^{\prime}}{N}
$$

\section{Dengan :}

$$
\sigma \mathrm{bm}=\text { Kuat tekan beton rata-rata }\left(\mathrm{kg} / \mathrm{cm}^{2}\right)
$$

$\sigma b i=$ Kuat tekan beton $\left(\mathrm{kg} / \mathrm{cm}^{2}\right)$

$\mathrm{N}=$ Jumlah seluruh sample

$$
S=\sqrt{\frac{\sum_{1}^{N}\left(\sigma^{\prime} b-\sigma^{\prime} b m\right)^{2}}{N-1}}
$$

Dengan :

$\mathrm{S} \quad=$ Deviasi standar $\left(\mathrm{kg} / \mathrm{cm}^{2}\right)$

$\sigma b i=$ Kuat tekan beton $\left(\mathrm{kg} / \mathrm{cm}^{2}\right)$

$\sigma \mathrm{bm}=$ Kuat tekan beton rata-rata $\left(\mathrm{kg} / \mathrm{cm}^{2}\right)$

$\mathrm{N} \quad=$ Jumlah seluruh sample $\sigma \mathrm{bk}=\sigma \mathrm{bm}-1,64$

Dengan :

$\sigma b k=$ Kuat tekan beton karakteristik $\left(\mathrm{kg} / \mathrm{cm}^{2}\right)$

$1,64=$ Konstanta

$\mathrm{S} \quad=$ Deviasi standar $\left(\mathrm{kg} / \mathrm{cm}^{2}\right)$

\section{METODOLOGI PENELITIAN}

\section{A. Persiapan Alat dan Bahan}

Alat yang digunakan untuk mengambil data dalam penelitian ini sesuai dengan peralatan untuk pengujian masing-masing bahan yang ada pada Laboratorium Fakultas Teknik Universitas Palembang. Peralatan ini hendaknya digunakan dalam keadaan bersih dan layak pakai.
a. Alat-alat yang digunakan
1. Cetakan
2. Timbangan
3. Ayakan
4. Alat iji slump
5. Oven
6. Wadah adukan
7. Mesin uji kuat tekan

\section{b. Bahan-bahan yang digunakan \\ 1. Semen \\ 2. Agregat \\ - Agregat halus \\ - Agregat kasar}

3. Air

4. Sika Tilefix-200TA

\section{B. Pengujian Material}

Pengujian terhadap material dasar pembuat beton bertujuan untuk mengetahui karakteristik atau sifat-sifat dasar material yang akan digunakan sehingga dapat memudahkan dalam menentukan proporsi campuran beton.

a. Agregat halus

- Analisa saringan agregat halus

- Analisa spesific gravity dan penyerapan agregat halus

- Berat isi agregat halus

- Kadar lumpur agregat halus

b. Agregat kasar

- Analisa saringan agregat kasar

- Analisa spesific gravity dan penyerapan agregat kasar

- Berat isi agregat kasar 


\section{- Pengujian keausan agregat kasar}

\section{Desain Campuran Beton}

Sebelum kita melakukan pencampuran adukan untuk pembuatan benda uji kita harus terlebih dahulu mengetahui kapasitas adukan yang kita perlukan, adapun istilah lain dari rencana adukan tersebut adalah mix design concrete. Bahan-bahan yang kita perhitungkan untuk campuran beton adalah agregat kasar, agregat halus, semen, air dan bahan pengganti semen. Rencana adukan tersebut dibuat berdasarkan dari uji bahan yang kita lakukan sebelumnya dan berdasarkan jumlah serta ukuran benda uji yang kita rencanakan untuk dibuat.

\section{Pengujian Slump}

Tujuan dilakukan pengujian slump ini adalah untuk menentukan ukuran derajat kemudahan pengecoran adukan beton segar dengan menggunakan alat Abrams yaitu alat yang berupa kerucut terpancung.

\section{E. Perawatan Benda Uji}

Setelah umur beton mencapai 24 jam dari saat pengecoran, maka cetakan dibuka dan dilakukan perawatan terhadap benda uji sampai saat pengujian. Perawatan benda uji adalah dengan cara direndam. Benda uji berada dalam kondisi yang lembab untuk menghindari terjadinya penguapan kandungan air pada benda uji. Penguapan yang terjadi pada beton ini dapat menyebabkan terjadinya kehilangan air yang cukup banyak sehingga dapat menimbulkan terhentinya proses hidrasi yang sedang berlangsung pada campuran beton tersebut.

Selain itu penguapan yang terjadi pada beton dapat menyebabkan berkurangnya peningkatan kekuatan beton dan dapat juga menyebabkan terjadinya penyusutan kering yang terlalu cepat yang dapat mengakibatkan terjadinya retak-retak pada beton. Untuk itulah dilakukannya perawatan untuk data memperbaiki kualitas beton.

\section{F. Pengujian Kuat Tekan Benda Uji}

Bertujuan untuk mengetahui kuat beton yang dibuat apakah telah sesuai dengan yang telah direncanakan.
1) Peralatan yang dipakai antara lain:

a. Mesin tekan hydrolis

b. Timbangan kapasitas $20 \mathrm{~kg}$

2) Benda uji

Benda uji yang berbentuk kubus $15 \mathrm{~cm}$ x 15 $\mathrm{cm} \times 15 \mathrm{~cm}$

3) Prosedur pelaksanaan

a. Ambil benda uji berbentuk kubus yang mau diuji kuat tekanannya dari bak perendam dan keringkan terlebih dahulu

b. Tiap-tiap benda uji tersebut lalu ditimbang

c. Kemudian letakkan benda uji pada mesin tekan hydrolis

d. Periksa manometer mesin penekan, pastikan posisi jarum pada skala 0 . Kemudian dihidupkan mesin dan stel handle pada posisi penekan

e. Pembebanan diberikan secara kontinyu sampai pembacaan dial indicator yang berwarna hitam turun secara otomatis. Selanjutnya dicatat nilai maksimum beban yang dapat ditahan oleh benda uji maka akan terlihat nilai pada dial indicator

f. Kemudian keluarkan benda uji yang telah ditekan dan untuk benda uji selanjutnya sesuai dengan cara diatas.

\section{ANALISIS DAN PEMBAHASAN}

Beton yang bermutu baik yaitu apabila kuat tekannya tinggi, kuat tekan beton tinggi dipengaruhi oleh banyak factor misalnya kandungan semen tinggi, rasio air semen rendah, penggunaan agregat yang mutunya baik, agregat yang berkadar air rendah dan penggunaan bahan tambah atau bahan pengganti semen.

\section{A. Pemeriksaan Agregat Halus}

Pengujian laboratorium yang dilakukan untuk agregat halus meliputi berat isi gembur dan berat isi padat, analisa saringan, berat jenis dan penyerapan, kadar lumpur dan kadar air, agregat halus yang digunakan adalah pasir dari sungai musi.

Dari hasil pemeriksaan yang dilakukan di laboratorium Fakultas Teknik Universitas Palembang didapat data - data sebagai berikut: 
6. Pemeriksaan kadar air agregat kasar

\begin{tabular}{|l|c|c|}
\hline \multicolumn{1}{|c|}{ Pemeriksaan } & I (gram) & II (gram) \\
\hline Berat cawan $\left(\mathrm{W}_{1}\right)$ & 739 & 880 \\
\hline Berat cawan + Benda uji $\left(\mathrm{W}_{2}\right)$ & 1511 & 1731 \\
\hline Berat benda uji $\left(\mathrm{W}_{3}=\mathrm{W}_{2}-\mathrm{W}_{1}\right)$ & 772 & 851 \\
\hline $\begin{array}{l}\text { Berat cawan }+ \text { Benda uji kering oven } \\
\left(\mathrm{W}_{4}\right)\end{array}$ & 1484 & 1700 \\
\hline $\begin{array}{l}\text { Berat benda uji kering oven }\left(\mathrm{W}_{5}=\mathrm{W}_{4}\right. \\
\left.-\mathrm{W}_{1}\right)\end{array}$ & 745 & 820 \\
\hline \multirow{2}{*}{\begin{tabular}{l} 
Kadar air agregat $=\frac{W_{3}-W_{5}}{W_{5}} \mathrm{X} 100 \%$ \\
\cline { 2 - 4 }
\end{tabular}} & $3,624 \%$ & $3,780 \%$ \\
\cline { 2 - 3 } & \multicolumn{2}{|c|}{$\begin{array}{c}\text { Rata }- \text { rata }= \\
3,702 \%\end{array}$} \\
\hline
\end{tabular}

Dari hasil pengujian kadar air agregat kasar didapatkan persentase sebesar $3,702 \%$

7. Pemeriksaan kadar lumpur agregat kasar

\begin{tabular}{|l|c|c|}
\hline \multicolumn{1}{|c|}{ Pemeriksaan } & I (gram) & II (gram) \\
\hline Berat cawan $\left(\mathrm{W}_{1}\right)$ & 740 & 747 \\
\hline Berat cawan + Benda uji $\left(\mathrm{W}_{2}\right)$ & 1492 & 1401 \\
\hline Berat benda uji $\left(\mathrm{W}_{3}=\mathrm{W}_{2}-\mathrm{W}_{1}\right)$ & 752 & 654 \\
\hline $\begin{array}{l}\text { Berat cawan + Benda uji kering oven } \\
\left(\mathrm{W}_{4}\right)\end{array}$ & 1467 & 1381 \\
\hline $\begin{array}{l}\text { Berat benda uji kering oven }\left(\mathrm{W}_{5}=\mathrm{W}_{4}\right. \\
\left.-\mathrm{W}_{1}\right)\end{array}$ & 727 & 634 \\
\hline \multirow{2}{*}{\begin{tabular}{l} 
Kadar air agregat $=\frac{W_{3}-W_{5}}{W_{5}} \mathrm{X} 100 \%$ \\
\cline { 2 - 4 }
\end{tabular}} & $3,438 \%$ & $3,155 \%$ \\
\cline { 2 - 4 } & \multicolumn{2}{|c|}{$3,297 \%$} \\
\hline
\end{tabular}

Dari hasil pengujian kadar air agregat kasar didapatkan persentase sebesar 3,297\%

8. Pemeriksaan Berat Jenis dan Penyerapan

\begin{tabular}{|l|c|c|}
\hline \multicolumn{1}{|c|}{ Pemeriksaan } & I (gram) & II (gram) \\
\hline $\begin{array}{l}\text { Berat benda uji jenuh permukaan } \\
\text { kering (Bj) }\end{array}$ & 500 & 500 \\
\hline Berat benda uji kering oven (Bk) & 485 & 494 \\
\hline Berat piknometer + air $\left(\mathrm{W}_{2}\right)$ & 1198 & 1200 \\
\hline $\begin{array}{l}\text { Berat piknometer + Benda uji + air } \\
\left(\mathrm{W}_{1}\right)\end{array}$ & 1492 & 1485 \\
\hline Berat jenis kering = & $2,354 \%$ & $2,298 \%$ \\
\hline
\end{tabular}

\begin{tabular}{|c|c|c|}
\hline$\frac{B K}{\left(W_{2}+500-W_{1}\right)}$ & \multicolumn{2}{|c|}{ Rata - rata $=2,326$} \\
\hline \multirow{2}{*}{$\begin{array}{l}\text { Berat jenis SSD }= \\
\frac{B j}{\left(W_{2}+500-W_{1}\right)}\end{array}$} & $2,427 \%$ & $2,326 \%$ \\
\hline & \multicolumn{2}{|c|}{ Rata - rata $=2,377$} \\
\hline \multirow{2}{*}{ Penyerapan $=\frac{(B j-B k)}{B k} \times 100 \%$} & $3,093 \%$ & $1,215 \%$ \\
\hline & \multicolumn{2}{|c|}{$\begin{array}{c}\text { Rata }- \text { rata }= \\
2,154 \%\end{array}$} \\
\hline
\end{tabular}

\section{Pemeriksaan Berat Isi Gembur Agregat} kasar

\begin{tabular}{|l|c|c|}
\hline \multicolumn{1}{|c|}{ Pemeriksaan } & I (gram) & II (gram) \\
\hline Berat cawan $\left(\mathrm{W}_{1}\right)$ & 854 & 2211 \\
\hline Berat cawan + Benda uji $\left(\mathrm{W}_{2}\right)$ & 3212 & 5567 \\
\hline Berat benda uji $\left(\mathrm{W}_{3}=\mathrm{W}_{2}-\mathrm{W}_{1}\right)$ & 2358 & 3356 \\
\hline Volume cetakan $(\mathrm{V})$ & 1710,60 & 2493,46 \\
\hline Berat isi gembur $=\frac{W_{3}}{V}$ & 1,38 & 1,35 \\
\hline Berat isi gembur rata-rata & \multicolumn{2}{|c|}{$1,37 \mathrm{gr} / \mathrm{cm}^{3}$} \\
\hline
\end{tabular}

10. Pemeriksaan Berat Isi Padat Agregat kasar

\begin{tabular}{|l|c|c|}
\hline \multicolumn{1}{|c|}{ Pemeriksaan } & I (gram) & II (gram) \\
\hline Berat cawan $\left(\mathrm{W}_{1}\right)$ & 854 & 2211 \\
\hline Berat cawan + Benda uji $\left(\mathrm{W}_{2}\right)$ & 3516 & 6038 \\
\hline Berat benda uji $\left(\mathrm{W}_{3}=\mathrm{W}_{2}-\mathrm{W}_{1}\right)$ & 2662 & 3827 \\
\hline Volume cetakan $(\mathrm{V})$ & 1710,60 & 2493,46 \\
\hline Berat isi padat $=\frac{W_{3}}{V}$ & 1,56 & 1,54 \\
\hline Berat isi padat rata-rata & \multicolumn{2}{|c|}{$1,55 \mathrm{gr} / \mathrm{cm}^{3}$} \\
\hline
\end{tabular}

Dari hasil pemeriksaan berat isi agregat kasar, didapatkan berat isi agregat kasar rata - rata untuk keadaan gembur $=1,37$ $\mathrm{gr} / \mathrm{cm}^{3}$, sedangkan untuk berat isi agregat kasar rata - rata untuk keadaan padat $=1,55$ $\mathrm{kg} / \mathrm{cm}^{3}$ 
11. Pemeriksaan Analisa Saringan Agregat kasar

\begin{tabular}{|c|c|c|c|c|}
\hline \multirow{2}{*}{$\begin{array}{c}\text { Ukuran } \\
\text { Saringan } \\
(\mathrm{mm})\end{array}$} & \multicolumn{2}{|c|}{$\begin{array}{l}\text { Agregat } \\
\text { Tertahan }\end{array}$} & \multicolumn{2}{|c|}{$\begin{array}{c}\% \text { Kumulatif } \\
\text { Agregat }\end{array}$} \\
\hline & gram & $\%$ & Tertahan & Lolos \\
\hline 37,5 & 0 & 0 & 0 & 100 \\
\hline 19 & 11 & 0,37 & 0,37 & 99,63 \\
\hline 9,5 & 2477 & 82,56 & 82,93 & 17,07 \\
\hline 4 & 470 & 15,66 & 98,59 & 1,41 \\
\hline 2 & 2 & 0,07 & 98,66 & 1,34 \\
\hline 1 & 15 & 0,5 & 99,16 & 0,84 \\
\hline 0,5 & 5 & 0,17 & 99,33 & 0,67 \\
\hline 0,25 & 3 & 0,1 & 99.42 & 0,58 \\
\hline 0,125 & 2 & 0,07 & 99,5 & 0,5 \\
\hline 0,063 & 12 & 0,4 & 99,4 & 0,6 \\
\hline PAN & 3 & 0,1 & 100 & 0 \\
\hline Jumlah & 3000 & 100 & 877,36 & \\
\hline $\begin{array}{c}\text { Angka Ke } \\
\text { Total } \%\end{array}$ & $\begin{array}{l}\text { Iusan } \\
\text { mulat }\end{array}$ & retal & $=\frac{877,3}{100}$ & $=8,77$ \\
\hline
\end{tabular}

12. Data-data Pasir

\begin{tabular}{|l|l|l|}
\hline No & \multicolumn{1}{|c|}{ Uraian } & Keterangan \\
\hline 1 & Berat isi gembur & $1,091 \mathrm{gr} / \mathrm{cm}^{3}$ \\
\hline 2 & Berat Isi Padat & $1,269 \mathrm{gr} / \mathrm{cm}^{3}$ \\
\hline 3 & Berat jenis SSD & 2,427 \\
\hline 4 & Berat jenis kering & 2,362 \\
\hline 5 & Penyerapan & $2,775 \%$ \\
\hline 6 & Kadar Lumpur & $0,807 \%$ \\
\hline 7 & Kadar Air & $7,13 \%$ \\
\hline 8 & Gradasi Butiran & Zona 4 \\
\hline 9 & Modulus Kehalusan & 3,861 \\
\hline
\end{tabular}

13. Data-data kerikil

\begin{tabular}{|l|l|l|}
\hline No & \multicolumn{1}{|c|}{ Uraian } & Keterangan \\
\hline 1 & Berat isi gembur & $1,37 \mathrm{gr} / \mathrm{cm}^{3}$ \\
\hline 2 & Berat Isi Padat & $1,55 \mathrm{~kg} / \mathrm{cm}^{3}$ \\
\hline 3 & Berat jenis SSD & 2,377 \\
\hline 4 & Berat jenis kering & 2,326 \\
\hline 5 & Penyerapan & $2,154 \%$ \\
\hline 6 & Kadar Lumpur & $3,297 \%$ \\
\hline 7 & Kadar Air & $3,702 \%$ \\
\hline 8 & Modulus Kehalusan & 8,77 \\
\hline
\end{tabular}

14. Daftar Isian (formulir) Perencanaan Campuran Beton

\begin{tabular}{|c|c|c|c|}
\hline No & Uraian & $\begin{array}{c}\text { Tabel / } \\
\text { Grafik } \\
\text { Perhitunga } \\
n\end{array}$ & Nilai \\
\hline 1 & $\begin{array}{l}\text { Kuat tekan } \\
\text { yang } \\
\text { diisyaratkan }\end{array}$ & $\begin{array}{l}\text { Ditetapkan } \\
\text { Ayat 3.3.1 }\end{array}$ & $\begin{array}{l}16,9 \mathrm{MPa} \\
\text { pada } 28 \text { hari } \\
\text { bagian cacat } \\
5 \%\end{array}$ \\
\hline 2 & $\begin{array}{l}\text { Deviasi } \\
\text { Standar }\end{array}$ & Tabel 1 & $\begin{array}{l}7,5 \mathrm{~N} / \mathrm{mm}^{2} \\
\text { atau tanpa } \\
\text { data... N/mm }\end{array}$ \\
\hline 3 & $\begin{array}{l}\text { Nilai } \\
\text { Tambah } \\
\text { (margin) }\end{array}$ & $\begin{array}{l}\text { Ayat } 3.3 .2 \\
(1+3)\end{array}$ & $\begin{array}{l}(\mathrm{k}=1,64) \\
1,64 \times 7,5= \\
12,3 \mathrm{~N} / \mathrm{mm}^{2}\end{array}$ \\
\hline 4 & $\begin{array}{l}\text { Kekuatan } \\
\text { rata-rata } \\
\text { yang } \\
\text { ditargetkan }\end{array}$ & Ditetapkan & $\begin{array}{l}19,9+12,3 \\
=29,2 \mathrm{~N} / \\
\mathrm{mm}^{2}\end{array}$ \\
\hline 5 & Jenis semen & Ditetapkan & $\begin{array}{l}\text { Portland } \\
\text { Type I }\end{array}$ \\
\hline 6 & $\begin{array}{l}\text { Jenis } \\
\text { agregat : } \\
\text { kasar }\end{array}$ & & Batu Pecah \\
\hline & $\begin{array}{l}\text { Jenis } \\
\text { agregat : } \\
\text { halus }\end{array}$ & & Pasir \\
\hline 7 & $\begin{array}{l}\text { Faktor air } \\
\text { semen } \\
\text { bebas }\end{array}$ & $\begin{array}{l}\text { Tabel } 2 \\
\text { Grafik1/2 }\end{array}$ & $\begin{array}{l}0,56 \text { (ambil } \\
\text { nilai yang } \\
\text { terkecil) }\end{array}$ \\
\hline 8 & $\begin{array}{l}\text { Faktor air } \\
\text { semen } \\
\text { maksimum }\end{array}$ & $\begin{array}{l}\text { Ditetapkan } \\
\text { Ayat 3.3.2 }\end{array}$ & 0,61 \\
\hline 9 & Slump & Ditetapkan & $\begin{array}{l}\text { Slump } 60- \\
100 \mathrm{~mm}\end{array}$ \\
\hline 10 & $\begin{array}{l}\text { Ukuran } \\
\text { agregat } \\
\text { maksimum }\end{array}$ & $\begin{array}{l}\text { Tabel } 6 \\
\text { Ayat 3.3.4 }\end{array}$ & $38 \mathrm{~mm}$ \\
\hline 11 & $\begin{array}{l}\text { Kadar air } \\
\text { bebas }\end{array}$ & $\begin{array}{l}\text { Tabel } 6 \\
\text { ayat 3.3.5 }\end{array}$ & $185 \mathrm{~kg} / \mathrm{m}^{3}$ \\
\hline 12 & $\begin{array}{l}\text { Jumlah } \\
\text { semen }\end{array}$ & $11: 8$ atau 7 & $\begin{array}{l}185: 0,56= \\
330 \mathrm{~kg} / \mathrm{m}^{3}\end{array}$ \\
\hline 13 & $\begin{array}{l}\text { Jumlah } \\
\text { semen } \\
\text { maksimum }\end{array}$ & Ditetapkan & $352 \mathrm{~kg} / \mathrm{m}^{3}$ \\
\hline 14 & $\begin{array}{l}\text { Jumlah } \\
\text { semen } \\
\text { minimum }\end{array}$ & $\begin{array}{l}\text { Ditetapkan } \\
\text { Ayat3.3.2 }\end{array}$ & $275 \mathrm{~kg} / \mathrm{m}^{3}$ \\
\hline 15 & $\begin{array}{l}\text { Faktor air } \\
\text { semen yang } \\
\text { disesuaikan }\end{array}$ & Ditetapkan & 0,56 \\
\hline 16 & $\begin{array}{l}\text { Susunan } \\
\text { besar butir } \\
\text { agregat } \\
\text { halus }\end{array}$ & $\begin{array}{l}\text { Grafik } 3 \\
\text { s/d } 6\end{array}$ & $\begin{array}{l}\text { Daerah } \\
\text { gradasi } \\
\text { susunan } \\
\text { butir IV }\end{array}$ \\
\hline
\end{tabular}




\begin{tabular}{|c|c|c|c|}
\hline 17 & $\begin{array}{l}\text { Persen } \\
\text { agregat } \\
\text { halus }\end{array}$ & $\begin{array}{l}\text { Grafik 10- } \\
12\end{array}$ & $36 \%$ \\
\hline 18 & $\begin{array}{l}\text { Berat jenis } \\
\text { relatif, } \\
\text { agregat } \\
\text { (kering } \\
\text { permukaan) }\end{array}$ & & 2,473 \\
\hline 19 & $\begin{array}{l}\text { Berat jenis } \\
\text { beton }\end{array}$ & Grafik 13 & $1659 \mathrm{~kg} / \mathrm{m}^{3}$ \\
\hline 20 & $\begin{array}{l}\text { Kadar } \\
\text { agregat } \\
\text { gabungan }\end{array}$ & $\begin{array}{l}19-(12+ \\
11)\end{array}$ & $\begin{array}{l}1659-(330 \\
+185)= \\
1144 \mathrm{~kg} / \mathrm{m}^{3}\end{array}$ \\
\hline 21 & $\begin{array}{l}\text { Kadar } \\
\text { agregat } \\
\text { halus }\end{array}$ & $17 \times 20$ & $\begin{array}{l}36 \% \times 1144 \\
=411,84 \\
\mathrm{~kg} / \mathrm{m}^{3}\end{array}$ \\
\hline 22 & $\begin{array}{l}\text { Kadar } \\
\text { agregat } \\
\text { kasar }\end{array}$ & $20-21$ & $\begin{array}{l}64 \%-1144 \\
=732,16 \\
\mathrm{~kg} / \mathrm{m}^{3}\end{array}$ \\
\hline
\end{tabular}

\section{B. Hasil pengujian slump}

\begin{tabular}{|c|c|}
\hline Beton & $\begin{array}{c}\text { Nilai } \\
\text { slump } \\
(\mathrm{cm})\end{array}$ \\
\hline Normal & 6,3 \\
\hline Pengganti semen $10 \%$ & 7 \\
\hline Pengganti semen $20 \%$ & 8,7 \\
\hline Pengganti semen $30 \%$ & 9,3 \\
\hline
\end{tabular}

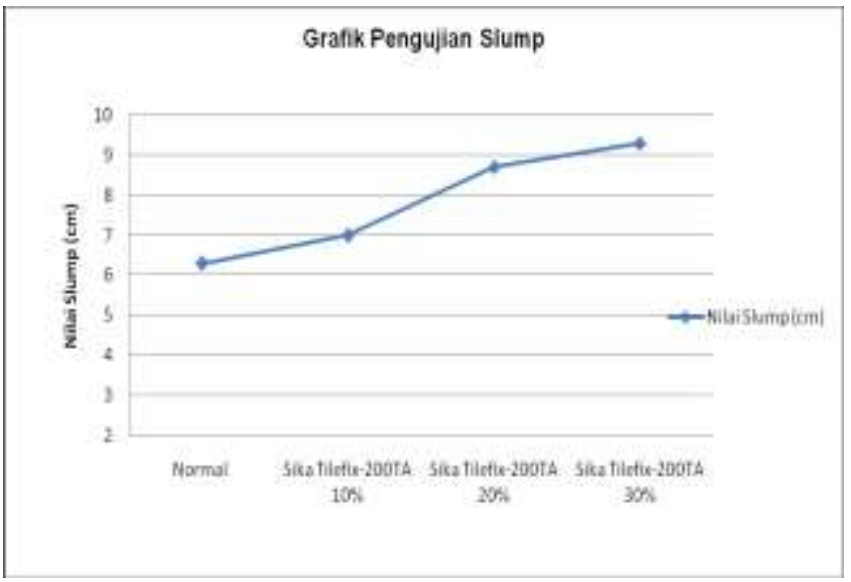

Berdasarkan grafik tersebut dapat diketahui bahwa slump yang dicapai mulai dari beton normal, beton dengan material Sika Tilefix-200TA sebagai bahan pengganti semen $10 \%, 20 \%, 30 \%$ masih memenuhi slump yang disyaratkan antara $60-100 \mathrm{~mm}$.

\section{Hasil Pengujian Kuat Tekan}

Rekapitulasi Evaluasi Hasil Uji Kuat Tekan Beton dengan material pengganti semen $10 \%, 20 \%$ dan $30 \%$ pada umur $7,14,21$ dan 28 hari

\begin{tabular}{|l|c|c|c|c|}
\hline \multirow{2}{*}{$\begin{array}{c}\text { Perlakuan } \\
\text { Beton } \\
\text { K.200 }\end{array}$} & \multicolumn{4}{|c|}{ Kuat Tekan (Kg/Cm²) } \\
\cline { 2 - 5 } & $\begin{array}{c}\text { Umur } \\
\text { Beton }\end{array}$ & $\begin{array}{c}\text { Umur } \\
\text { Beton }\end{array}$ & $\begin{array}{c}\text { Umur } \\
\text { Beton }\end{array}$ & $\begin{array}{c}\text { Umur } \\
\text { Beton }\end{array}$ \\
\hline $\mathbf{7 ~ H a r i ~}$ & $\mathbf{1 4 ~ H a r i}$ & $\mathbf{2 1 ~ H a r i}$ & $\mathbf{2 8 ~ H a r i}$ \\
\hline $\begin{array}{l}\text { Beton } \\
\text { Normal }\end{array}$ & 143,41 & 155,49 & 188,70 & 202,29 \\
\hline $\begin{array}{l}\text { Pengganti } \\
\text { semen 10\% }\end{array}$ & 140,40 & 152,47 & 184,17 & 197,76 \\
\hline $\begin{array}{l}\text { Pengganti } \\
\text { semen 20\% }\end{array}$ & 134,36 & 144,92 & 176,63 & 193,23 \\
\hline $\begin{array}{l}\text { Pengganti } \\
\text { semen 30\% }\end{array}$ & 129,83 & 141,91 & 175,12 & 190,21 \\
\hline
\end{tabular}

Sumber : Hasil uji Laboratorium

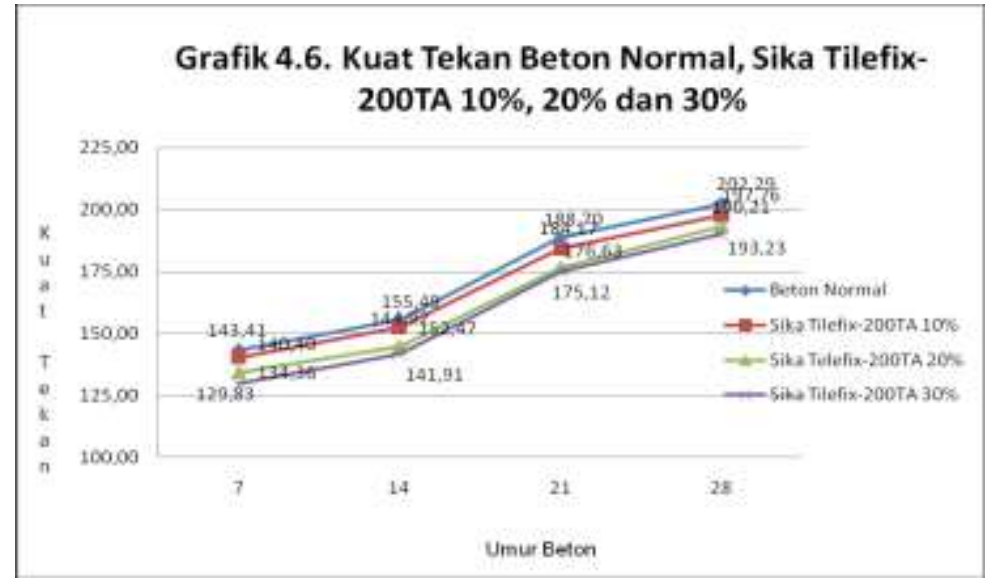

\section{KESIMPULAN}

Dari hasil penelitian yang dilakukan oleh peneliti di Laboratorium Fakultas Teknik Universitas Palembang didapat data-data yang kemudian diolah dan dianalisa, sehingga didapat hasil kuat tekan karakteristik beton dengan menggunakan Sika Tilefix-200TA sebagai bahan pengganti semen. 
1. Kuat tekan beton K.200 yang dihasilkan dari campuran Sika Tilefix-200TA sebagai pengganti semen sebanyak $0 \%, 10 \%, 20 \%$ dan $30 \%$ adalah :

- Beton K.200 normal tanpa menggunakan campuran Sika Tilefix200TA pengganti semen pada umur 28 hari didapat kuat tekan sebesar 202,29 $\mathrm{kg} / \mathrm{cm}^{2}$

- Beton K.200 yang menggunakan campuran Sika Tilefix-200TA pengganti semen sebesar $10 \%$ pada umur 28 hari didapat kuat tekan sebesar 197,76 $\mathrm{kg} / \mathrm{cm}^{2}$.

- Beton K.200 yang menggunakan campuran Sika Tilefix-200TA pengganti semen sebesar $20 \%$ pada umur 28 hari didapat kuat tekan sebesar 193,23 $\mathrm{kg} / \mathrm{cm}^{2}$.

- Beton K.200 yang menggunakan campuran Sika Tilefix-200TA pengganti semen sebesar $30 \%$ pada umur 28 hari didapat kuat tekan sebesar 190,21 $\mathrm{kg} / \mathrm{cm}^{2}$.

2. Dari hasil kuat tekan yang didapat pada pengujian, beton yang menggunakan campuran Sika Tilefix-200TA sebagai pengganti semen sebesar $10 \%, 20 \%$ dan $30 \%$ tidak mempunyai kuat tekan yang melebihi dari beton K.200 normal (0\% campuran Sika Tilefix-200TA sebagai pengganti semen)

\section{DAFTAR PUSTAKA}

[1] Samekto, Wuryati dan Rahmadiyanto, Candra.2001. Teknologi Beton. Penerbit : Kanisius. Yogyakarta.

[2] Tjokrodimuljo, Kardiyono., 1998, "Teknologi Beton", Buku Ajar Pada Jurusan Teknik Sipil, Fakultas Teknik, Universitas Gajah Mada. Yogyakarta.

[3] Tjokrodimuljo, Kardiyono, 2007, Teknologi Beton, Buku Ajar. Jurusan Teknik Sipil, Universitas Gajah Mada. Yogyakarta.

[4] Samekto,Wuryati., Candra Rahmadiyanto, Teknologi Beton, (Yogyakarta: Kanisius ,2001).

[5] A. Sjafei.,2005,. Teknologi Beton A-Z. Edisi Pertama, Yayasan Jhon Hi-ech Idetama, UI-Press, Jakarta.

[6] SK.SNI.T-15-1990-3 "Tata Cara Pembuatan Rencana Campuran Beton Normal". Badan Standarisasi nasional

[7] SNI 03-1970-2008 Cara Uji Berat Jenis dan penyerapan air agregat halus, Badan Standarisasi Nasional

[8] Mulyono, T. 2003. Teknologi Beton. Andi: Yogyakarta.

[9] Bayu Krisfinanto : Metode Perawatan Beton (Curing), bayugembell.blogspot.co.id 2011.

[10] Tjokrodimulyo, K. 1996. Teknologi Beton. Nafiri: Yogyakarta.

[11] SNI 03-1968-1990 Metode Pengujian Analisa Saringan Agregat halus dan Kasar, Badan Standarisasi Nasional

[12] SNI 03-1972-1990 Metode Pengujian Slump Beton, Badan Standarisasi Nasional 